\title{
開催報告（国際会議 CANDAR2016）
}

\author{
中野 浩嗣藤田 聡 \\ 広島大学
}

\author{
藤原一毅 鯉㴊 道紘 \\ 情報通信研究機構国立情報学研究所
}
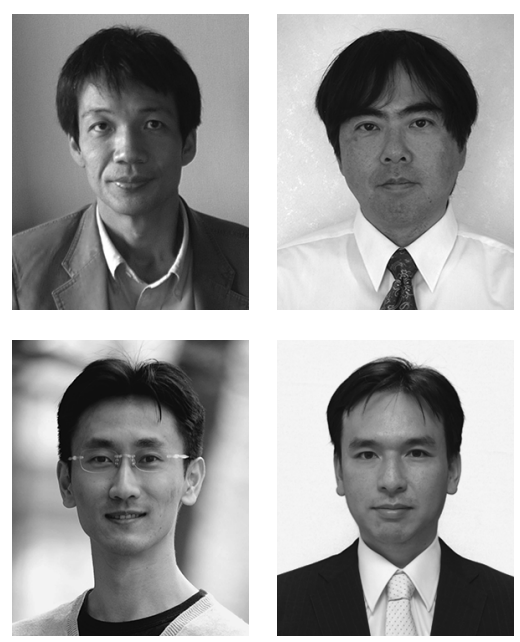

CANDAR (International Symposium on Computing and Networking, http://is-candar.org/) は，コンピューティングとネットワーキングに 関する幅広い分野を扱う国際会議である，前身 の ICNC (International Conference on Networking and Computing) を含めると，2016 年は 7 回 目にあたり，11月 $22 ２ 5$ 日まで東広島芸術文化 ホール「くらら」において開催された。電子情報 通信学会コンピュータ・システム研究会 (CPSY) と情報処理学会システム・アーキテクチャ研究 会 (ARC) の共催 (Technically cosponsored) であ り, 論文集はIEEEから出版され, IEEEのデジ タルライブラリに収録される。通常の参加登録 者は約 200 名で，のべ 123 件の発表があった. 今 回は, 発表のない学生の参加は無料とし, 参加 登録を募った結果，約 50 名の登録があった。の ベ約 250 名の参加者による 4 日間の発表と討論 が行われた。

メインシンポジウムは 5 つのトラック (Algorithms and Applications, Architecture and Computer System, Networking and Grid, Software and Middleware, Information and Computer Security) から構成され，合計 79 件の投稿があり， 8 件が Long Paper, 18 件が Regular Paper とし て採択された，採択率は $33 \%$ であり，質の高い論
文が選ばれた。また，併設の 8 つのワクショッ プでは，合計 87 件の発表があり，GraphGolf コ ンペティションで 3 件の発表があった.さらに, 2 件のメインシンポジウム基調講演と，8件のワー クショップ基調講演が行われた.メインシンポジ ウム全体で評価の高かった論文 1 件を CANDAR Best Paper，各トラックで優れた論文を 1 件（計 5 件）をCANDAR Outstanding Paper として表 彰した。ワークショップ全体で評価の高い Poster 論文を Workshop Best Poster Paperに選び，ま た，ワークショップごとに優れた論文を 1 件ず つ表彰した。

CANDAR では 2 つのジャーナル杂誌特集号 を計画している. IEICE Transactions on Information and Systems と International Journal of Networking and Computing の 2 つの論文誌に 特集号を企画しており，本シンポジウムとその ワークショップで発表した論文の拡張版を再査 読の上，掲載する予定である。

2017 年は JR 青森駅近くの青森観光物産館（ア スパム）で11月19日（日） 22 日（水）にて 開催する.メインシンポジウムの投稿締め切り は 6 月下旬を予定している. 